Prace Historyczno-Archiwalne t. XXXIII, Rzeszów 2021

ISSN: 1231-3335

\title{
RECENZJE
}

\section{Barbara Faron, Piastówny na tronach Europy, Wydawnictwo Astra s.c., Kraków 2019, ss. 584 + ilustr.}

$\mathrm{P}$

od koniec 2019 roku, staraniem krakowskiego Wydawnictwa Astra s.c., ukazało się na rynku księgarskim pierwsze wydanie pracy autorstwa Barbary Faron pt. Piastówny na tronach Europy.

Autorka jest niewątpliwie wybitną pisarką oraz doświadczonym i zamiłowanym w dawnych dziejach historykiem. Jest absolwentką Uniwersytetu Jagiellońskiego; pracuje jako nauczycielka języka polskiego i historii w jednej z krakowskich szkół. Od wielu już lat współpracuje też z różnymi wydawnictwami. Niewątpliwie lubi pisać historię niejako na nowo, ale przy tej okazji fascynuje się różnymi zagadkami historycznymi z dawno minionych dziejów.

Barbara Faron jest autorką m.in. takich książek, jak: Siedem śmierci. Jak umierano $w$ dawnych wiekach czy Święte i tygrysice. Piastówny i żony Piastów 1138-1320 oraz wielu innych publikacji, w tym także artykułów popularno-naukowych i naukowych z zakresu szeroko pojmowanej humanistyki. Co więcej, w jej dorobku literackim znajdują się również powieści dla dzieci i młodzieży.

Omawiana tu praca Piastówny na tronach Europy to publikacja niezwykle interesująca z wielu względów. Książka ta jest też ze wszech miar godna uwagi i polecenia nie tylko badaczom - zawodowym historykom, zajmującym się w swej pracy naukowej poznawaniem oraz zgłębianiem dawnych dziejów, ale także i wszystkim Czytelnikom interesującym się życiem codziennym w dawnych wiekach w Europie Środkowo-Wschodniej oraz ciekawymi postaciami, które ją zamieszkiwały.

Z pewnością warto, aby po książkę sięgnęły osoby zainteresowane polityką prowadzoną wówczas w tej części Europy przez poszczególne rody, zarówno książęce, jak i królewskie, a nawet cesarskie. Przede wszystkim jednak jest to praca poświęcona kobietom wywodzącym się z rodu Piastów oraz roli, jaką odgrywały one w ówczesnej polityce - dynastycznej, wewnętrznej poszczególnych krajów, jak i międzynarodowej.

Jak słusznie zauważa autorka pracy, nie zawsze osobom poszczególnych Piastówien ówczesne roczniki i kroniki poświęcały dostatecznie wiele uwagi. A jednak to one: córki i siostry Piastów odegrały bardzo ważną rolę w prowadzonej przez swych ojców czy braci polityce, bo to one i ich małżeństwa miały być gwarancją trwałości układów, zawieranych przez polski ród piastowski z: czeskimi Przemyślidami, węgierskimi Arpadami, ruskimi Rurykowiczami, niemieckimi Askańczykami czy Wittelsbachami oraz innymi dynastiami średniowiecznej Europy.

Bardzo często też kobiety wywodzące się z rodu Piastów nadawały ton ówczesnemu życiu społecznemu oraz kulturalno-religijnemu na dworach swych mężów. 
Oprócz tego zajmowały się, oczywiście, przede wszystkim wychowaniem potomstwa, jego wykształceniem i przygotowaniem do przyszłych ról społecznych - jak wiadomo, bardzo często byli to przyszli władcy.

Niekiedy Piastówny uczestniczyły w pertraktacjach pomiędzy swymi nowymi rodzinami a Piastami. Często, pozostawione wdowami przez swych przedwcześnie zmarłych mężów, przejmowały władzę w kraju i sprawowały ją w imieniu małoletnich synów.

Autorka przedstawia w swej książce portrety poszczególnych kobiet wywodzących się z rodu Piastów na tle ówczesnych, najczęściej burzliwych i skomplikowanych stosunków międzynarodowych i dynastycznych. Wszak bez genealogii rodów panujących nie można zrozumieć ani naprawdę poznać dziejów Średniowiecza.

Przedstawiając swe bohaterki, pisarka-historyczka ukazuje je, poczynając od postaci wręcz legendarnych: Białej Knegini i Światosławy (Sygrydy Storrady); osobowości wpływowych zwłaszcza w okresie swego wdowieństwa, takich jak pierwsza królowa Czech Świętosława (Swatawa), Ryksa Elżbieta słynąca ze swej niezwykłej urody czy też potężna Elżbieta Łokietkówna, aż po znane źródłom historycznym jedynie pośrednio córki wielkich królów czy nawet mało znaczące przedstawicielki dynastii piastowskiej.

Spośród czterdziestu dwóch scharakteryzowanych przez autorkę córek lub sióstr Piastów, aż czternaście - wliczając w to dwie koronowane władczynie Polski, tj. Jadwigę Kaliską i Jadwigę Żagańską - zostało królowymi lub nawet cesarzowymi.

Były wśród nich m.in.: Ryksa Śląska (cesarzowa Hiszpanii i żona Alfonsa VII Imperatora), Anna Świdnicka - cesarzowa Cesarstwa Rzymskiego Narodu Niemieckiego, Ryksa Bolesławówna, która była żoną dwóch królów Szwecji i księcia nowogrodzkiego, a także matką króla Danii.

Autorka przedstawia w swej pracy często skomplikowane relacje łączące Piastów z wieloma ówczesnymi rodami panującymi, zarówno tymi ze Wschodu, jak i Zachodu, Południa i Północy Europy. Różnie i w różnym czasie układały się ich wzajemne relacje. Niekiedy Piastowie zaciekle rywalizowali i walczyli, niekiedy zawierali przyjaźnie czy sojusze, których gwarancję miała stanowić ręka córki lub siostry. Oczywiście, bywało też odwrotnie i to Piastowie brali swe żony spośród rodów panujących średniowiecznej Europy.

Praca Piastówny na tronach Europy składa się z sześciu części, w których historyczka przedstawiła, zarówno w oparciu o źródła historyczne, jak i dotychczasową literaturę przedmiotu (zestawioną następnie w bardzo bogatej i obszernej Bibliografii na końcu publikacji), liczne postacie kobiet z dynastii piastowskiej.

W części pierwszej, zatytułowanej Na tronie Przemyślidów, są to: Świętosława (Swatawa), Elżbieta Mieszkówna, Adelajda Zbysława, Ryksa Przemysłówna (Ryksa Elżbieta), Wiola Elżbieta, Anna Świdnicka i Elżbieta Pomorska.

Bohaterkami części drugiej - Na tronie Arpadów - są kolejne Piastówny: Adelajda, nieznana z imienia córka Mieszka II, Salomea Piastówna, Fenenna Kujawska, Maria Bytomska, Elżbieta Łokietkówna, Elżbieta Kujawska, Anna Kazimierzówna, Jadwiga Kazimierzówna.

W trzeciej części pt. Ruskie i litewskie mariaże występują: nieznana z imienia córka Bolesława Chrobrego, Gertruda Mieszkówna, Agnieszka Bolesławówna, Dubrawa Mazowiecka, Eufemia Kujawska, Eufemia Mazowiecka, Katarzyna Mazowiecka. 
Część czwarta przedstawia Piastówny U boku niemieckich książąt i magnatów. Były to: Regelinda, Matylda, Judyta Bolesławówna, Dobroniega Ludgarda, Konstancja Przemysłówna, Kunegunda Łokietkówna, Barbara Legnicka, Eufemia Oleśnicka, Judyta Świdnicka, Beatrycze Świdnicka, Małgorzata Brzeska, Kunegunda Kazimierzówna.

Egzotyczne małżeństwa opisała autorka w części piątej, której bohaterkami są: Świętosława (Sygryda Storrada), Ryksa Bolesławówna, Anastazja Mieszkówna, Elżbieta Kazimierzówna i Ryksa Śląska. Ostatnia, szósta część to Ostatnie z rodu - Anna Mazowiecka i Karolina Piastówna.

Na końcu swej pracy autorka zamieściła przypisy do poszczególnych biogramów i bardzo obszerną Bibliografię. Książka jest bogato ilustrowana, z podaniem źródeł fotografii.

W efekcie powstała bardzo interesująca publikacja, którą warto polecić nie tylko miłośnikom średniowiecza, ale każdemu zainteresowanemu historią.

Bogdan Stępień

ORCID 0000-0003-0151-4866

DOI:10.30657/pha.33.2021.19

(historyk, Łańcut)

e-mail: bogstep@interia.pl 